\title{
Plant biopolymer-geopolymer: organic diagenesis and kerogen formation
}

\author{
Neal S. Gupta* \\ Department of Science and Technology, Bryant University, Smithfield, RI, USA
}

Keywords: kerogen, biopolymer degradation, neogenesis, selective preservation, decay, molecular paleontology, organic geochemistry

Sedimentary organic matter is formed by diagenesis (reactions in sediments up to $60^{\circ} \mathrm{C}$, Tegelaar et al., 1989) and catagenesis (those $>100^{\circ} \mathrm{C}$ induced by thermal cracking, Tissot and Welte, 1984) of biological material introduced during deposition from primary producers. Over $90 \%$ of this sedimentary organic matter is a non-hydrolyzable (i.e., immune to acid-base hydrolysis) macropolymer called kerogen (de Leeuw and Largeau, 1993) that does not dissolve in organic solvents and produces petroleum upon catagenesis (Tissot and Welte, 1984). The composition and type of kerogen is heavily dependent on the nature of the biological input (de Leeuw et al., 2006), the environment of deposition (Goth et al., 1998), and the preservation pathway (diagenesis, Briggs, 1999). Both diagenesis and catagenesis can be simulated in the laboratory using P-t apparatus (Stankiewicz et al., 2000) and environmental decay experiments (Briggs, 1999; Gupta et al., 2009).

Kerogen formation is generally attributed to neogenesis (Tissot and Welte, 1984), in which sedimentary organic matter is formed by random intermolecular polymerization and polycondensation of biological residues (e.g., amino acids, sugars, and lipids) including melanoidins or the Selective Preservation of resistant biosynthesized macromolecules that undergo limited chemical change during diagenesis (i.e., they remain morphologically and chemically recognizable as organic remains in the sedimentary rock; Goth et al., 1998). Selective preservation which has gained widespread acceptance as a counter thesis to neogenesis since the mid-1980s posits that aliphatics in fossil organic matter are derived from highly aliphatic and resistant (insoluble and non-hydrolyzable) biopolymers in living organisms, such as algaenan (present in algae; Goth et al., 1998), cutan (present in plant leaves; Mösle et al., 1998), and suberan (present in suberinized vascular tissue, de Leeuw and Largeau, 1993). These survive decay more readily than labile biopolymers such as polysaccharides, proteins, and nucleic acids (Tegelaar et al., 1989). A thorough geochemical analysis of organic fossil matter using high-resolution spectroscopy in conjunction with mass spectrometry [such as in Goth et al. (1998)] and laboratory analytical chemistry methods (de Leeuw and Largeau, 1993) establishes the diagenetic pathway degree of biological preservation (Briggs, 1999) and insights into geochemical transformation of biomolecules to geomolecules (Gupta et al., 2009). Organic sulfurization (Kok et al., 2000) and oxidative reticulation of unsaturated cross-linkages in reacting molecules (Riboulleau et al., 2001) offer mechanistic insights through analysis and case study of modern (extant) and fossil material (discrete) or those disseminated in sediment as kerogen. In light of this, this synthesis opinion article focuses on complimentary and conflicting arguments from plant fossil analysis, their widespread relevance, the biochemical description of contributors, insights from controlled laboratory experiments (decay), and simulated autoclave experiments in pressure-temperature regimes from 270 to $350^{\circ} \mathrm{C}$ (Stankiewicz et al., 2000).

Morphology and chemical structure of fossil leaves from the Ardèche diatomite (Late Miocene, from southeast France) were detected using pyrolysis-gas chromatography-mass spectrometry, tetramethylammoniumhydroxide (TMAH)-assisted pyrolysis, micro-FTIR, and solid-state ${ }^{13} \mathrm{C}$ NMR spectroscopy to improve understanding of these questions (Gupta et al., 2007a). 
These revealed the presence of benzene derivatives, lignin, pristenes, fatty acids, and an aliphatic geopolymer (insoluble in organic solvents, hence recalcitrant) similar in composition to kerogen. Modern leaves failed to reveal the presence of cutan (the aliphatic biopolymer that has been posited to be the direct source of aliphatics in leaf fossils), thereby precluding selective preservation of cutan as the source (Gupta et al., 2007a). TMAHassisted pyrolysis (an online hydrolysis method) supported this argument by releasing incorporated fatty acyl moieties ranging in $\mathrm{C}$ number from $\mathrm{C}_{8}$ to $\mathrm{C}_{32}$ from the macromolecule. The $\mathrm{C}_{10}$ to $\mathrm{C}_{32}$ acid units are characteristic of the free fatty acid from epicuticular waxes in modern leaves and also phospholipid fatty acid (PLFA) fraction of cell membranes (Gupta et al., 2007a) indicating their direct chemical incorporation in the fossil leaf geopolymer. Such lipid cross-linking is seen in fossil dinoflagellates as well (Versteegh et al., 2004). Cutan, the resistant non-hydrolyzable aliphatic biopolymer present in modern leaves (Mösle et al., 1998), was first reported in the cuticle of Agave americana and has generally been considered ubiquitous in leaf cuticles along with the biopolyester cutin. Because leaves and cuticles in the fossil record almost always have an aliphatic composition (Mösle et al., 1998), cutan has been argued as the source biopolymer, especially for the aliphatic component $>\mathrm{C}_{20}$. However, Gupta et al. (2006a) analyzed modern leaves using chemical degradation techniques to test for the presence of cutan in multiple taxa concluding its absence in 16 out of 19 taxa analyzed (including gymnosperms and angiosperms). Cutin that forms the protective biopolymerpolyester in modern leaf cuticles (with $\mathrm{C}_{16}$ and $\mathrm{C}_{18}$ hydroxy fatty acids as abundant components) also acts as a possible source in fossils (Mösle et al., 1998; Gupta et al., 2007a). Other studies that offer similar examples of geopolymer formation in fossils include insects (Briggs, 1999; Stankiewicz et al., 2000), graptolites (Gupta et al., 2006b), kerogen (showing oxidative cross-linking with less selective preservation; Riboulleau et al., 2001), sporopollenin (Watson et al., 2012), and fossil algae (Versteegh et al., 2004).

Degradation of polysaccharides by microbes is dictated by the presence of polysaccharide utilization loci (PUL) in genomes of microbes that dictates which sugars can be utilized by the microbial consortia for energy. Hence, studies have been conducted to understand the relative rate of decay of plant biopolymers (Gupta et al., 2009 and references therein), e.g., by analysis of modern (decaying) and fossil Metasequoia leaves. These revealed the presence of structural polyester cutin, guaiacyl lignin units (typical of gymnosperms), and polysaccharides. Analysis of environmentally decayed leaves revealed that the lignin units and cellulose were degraded more relative to cutin, suggesting that cutin is likely more stable than lignin and cellulose in this environmental setting. This is supported by electron microscopy of changes in the

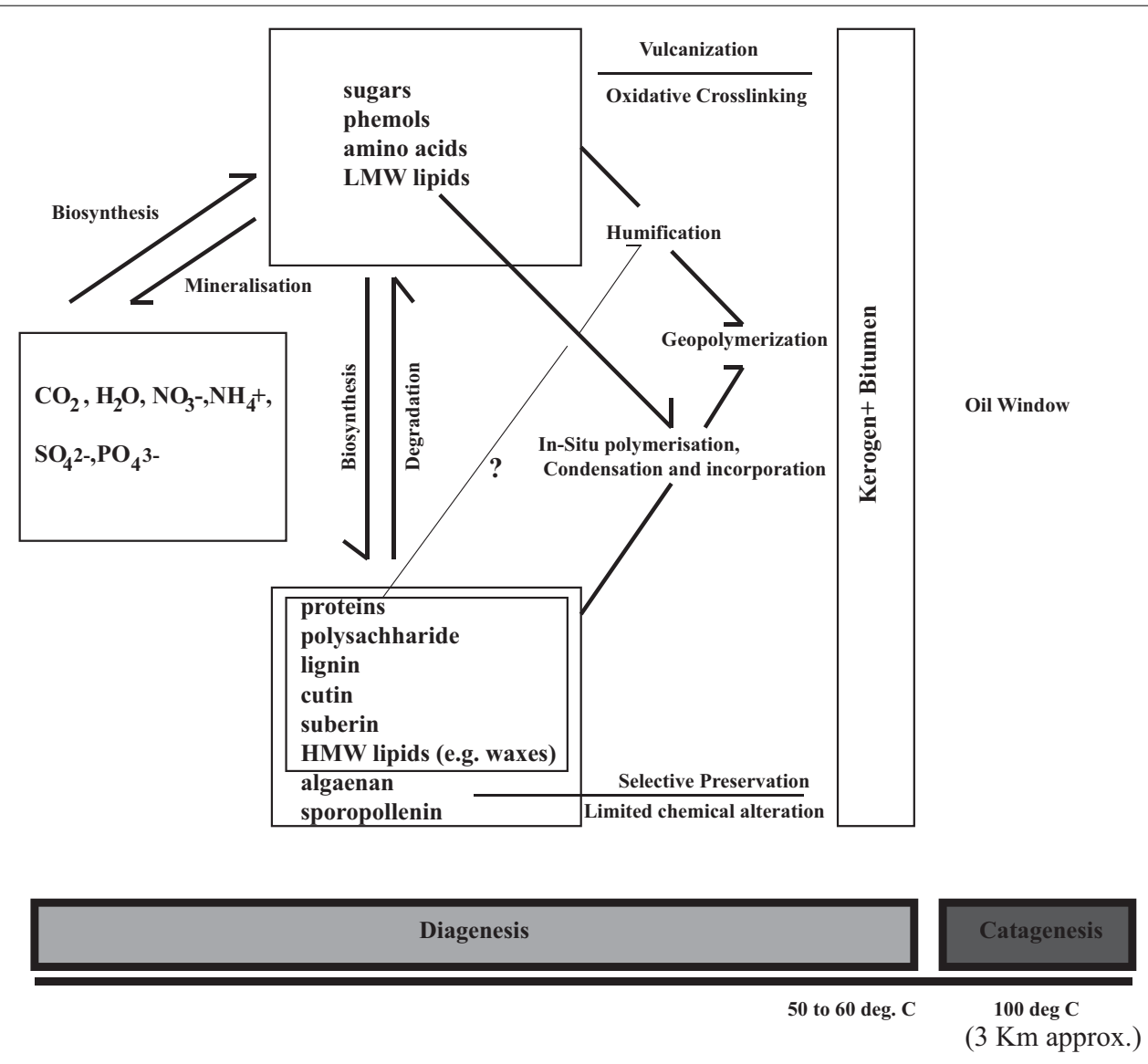

FIGURE 1 | A concept diagram proposing and integrating the pathways of organic matter preservation in tandem with selective preservation (that requires presence and limited change of precursor recalcitrant biopolymer). 
cellular structure and cuticle of the modern, decayed, and fossil Metasequoia (Gupta et al., 2009).

Experimental heating of cutin is known to generate an aliphatic polymer with carbon chain length $<\mathrm{C}_{20}$ (Gupta et al., 2007b), demonstrating that the $n$-alkyl component $>\mathrm{C}_{20}$ is a product of incorporation of long-chain plant waxes (indicated by the odd over even predominance of the $>\mathrm{C}_{27} n$-alkanes) when cutan is absent in the modern leaf. The resistant nature of cutin compared with lignin and polysaccharides explains the ubiquitous presence of an $n$-alkyl component $\left(<\mathrm{C}_{20}\right)$ in fossil leaves even when polysaccharides are absent and lignin has decayed (Gupta et al., 2009). Experimental maturation of cutan, cutin, lipid waxes, lignin, and polysaccharides in plant leaves (and model compounds - 270 to $350^{\circ} \mathrm{C}, 700$ bars) generated a resistant nonhydrolyzable aliphatic macromolecule similar to that detected in plant fossils (Gupta et al., 2007b); Stankiewicz et al. (2000) used similar methods for insects. By comparing the products derived from maturation of different pre-treated plant tissues, these experiments demonstrated that lipids are incorporated into the macromolecular material at $350^{\circ} \mathrm{C}$ (Gupta et al., 2007b; Figure 1 shows a new integrated concept diagram). Thus, they indicate that labile organic compounds are a potential source of the aliphatic component of fossil organic matter and kerogen in the absence of a resistant aliphatic precursor in the living organism.

The mechanism leading to the formation of aliphatic components in petroleum from algal sources in marine kerogens is posited to derive from algaenan present in outer cell walls of algae

\section{References}

Briggs, D. E. G. (1999). Molecular taphonomy of animal and plant cuticles: selective preservation and diagenesis. Philos. Trans. R. Soc. Lond. B 354, 7-16. doi:10. 1098/rstb.1999.0356

de Leeuw, J. W. (2007). On the origin of sedimentary aliphatic macromolecules: a comment on recent publications by Gupta et al. Org. Geochem. 38, 1585-1587. doi:10.1016/j.orggeochem.2007.05.010

de Leeuw, J. W., and Largeau, C. (1993). "A review of macromolecular organic compounds that comprise living organisms and their role in kerogen, coal and petroleum formation," in Org. Geochem.: Prin. and App, eds M. H. Engel and S. A. Macko (New York: Plenum Press), 23-62.

de Leeuw, J. W., Versteegh, G. J. M., and van Bergen, P. F. (2006). Biomacromolecules of plants and algae and their fossil analogues. Plant Ecol. 189, 209-233. doi:10.1007/s11258-005-9027-x

Goth, K., de Leeuw, J. W., Puttman, W., and Tegelaar, E. W. (1998). Origin of messel oil shale kerogen. Nature 336, 759-761. doi:10.1038/336759a0

Gupta, N. S., Briggs, D. E. G., Collinson, M. E., Evershed, R. P., Michels, R., Jack, K. S., et al. (2007a). Evidence for the in situ polymerisation of labile aliphatic organic compounds during the preservation of fossil leaves: implications for organic matter preservation. Org. Geochem. 38, 499-522. doi:10.1016/j.orggeochem. 2006.06.011

Gupta, N. S., Michels, R., Briggs, D. E. G., Collinson, M. E., Evershed, R. P., and Pancost, R. D. (2007b). Experimental evidence for formation of geomacromolecules from plant leaf lipids. Org. Geochem. 38, 28-36. doi:10.1016/j.orggeochem.2006. 09.014

Gupta, N. S., Collinson, M. E., Briggs, D. E. G., Evershed, R. P., and Pancost, R. D. (2006a). Re-investigation of the occurrence of cutan in plants: implications for the leaf fossil record. Paleobiology 32, 432-449. doi:10.1666/ 05038.1

Gupta, N. S., Briggs, D. E. G., and Pancost, R. D. (2006b). Molecular taphonomy of graptolites. J. Geol. Soc. Lond. 163, 897-900. doi:10.1144/0016-7649 2006-070
(Goth et al., 1998). Experiments on the non-algaenan-producing alga Chlamydomonas reinhardtii at 260 and $350^{\circ} \mathrm{C}$ revealed a macromolecule with significant aliphatic component (Gupta et al., 2014) similar to that in the modern leaf experiments, also similar to high $\mathrm{H}$ content kerogens; derived directly from saturated and unsaturated $\mathrm{C}_{16}$ and $\mathrm{C}_{18}$ fatty acids here. The presence of amides, nitriles, and oximes in the heated algae is due to the reaction of lipids with the $\mathrm{N}$-containing protein molecules as also seen in heated insects (Gupta et al., 2014). Scenedesmus quadricauda at $350^{\circ} \mathrm{C}$ (an algaenan-containing green alga - as a control) demonstrated survival of algaenan at these temperatures. Analysis of the solvent-insoluble residue of heated cyanobacterium (Oscillatoria sp.) and Rhodopseudomonas palustris (purple nonsulfur-containing bacteria) similarly produced a macromolecule with high aliphatic content in these studies. Algaenan thus does not give rise to a ubiquitous aliphatic composition in marine sedimentary organic matter (Goth et al., 1998) as a preserved biopolymer. These renew interests and caveats in organic diagenesis and selective preservation of biopolymers (such as algaenan and cutan) and their effect on long-term carbon sequestration (de Leeuw, 2007), where occurrence of recalcitrant biomolecules is limited in modern taxa.

\section{Acknowledgments}

Prof. Derek Briggs (FRS), Prof. Chris Reid (Bryant University), and a Frontiers reviewer are thanked for initial review.

Gupta, N. S., Steele, A., Fogel, M., Griffin, P., Adams, M., Summons, R. E., et al (2014). Experimental formation of geomacromolecules from microbial lipids. Org. Geochem. 67, 35-40. doi:10.1016/j.orggeochem.2013.11.006

Gupta, N. S., Yang, H., Leng, Q., Briggs, D. E. G., Cody, G. D., and Summons, R. E. (2009). Diagenesis of plant biopolymers: decay and macromolecular preservation of Metasequoia. Org. Geochem. 40, 802-809. doi:10.1016/j.orggeochem. 2009.04.004

Kok, M. D., Schouten, S., and Sinninghe Damsté, J. S. (2000). Formation of insoluble, nonhydrolyzable, sulfur-rich macromolecules via incorporation of inorganic sulfur species into algal carbohydrates. Geochim. Cosmochim. Acta 64, 2689-2699. doi:10.1016/S0016-7037(00)00382-3

Mösle, B., Collinson, M. E., Finch, P., Stankiewicz, B. A., Scott, A. C., and Wilson, R. (1998). Factors influencing the preservation of plant cuticles: a comparison of morphology and chemical comparison of modern and fossil examples. Org. Geochem. 29, 1369-1380. doi:10.1016/S0146-6380(98)00080-1

Riboulleau, A., Derenne, S., Largeau, C., and Baudin, F. (2001). Origin of contrasting features and preservation pathways in kerogens from the Kashpir oil shales (Upper Jurassic, Russian Platform). Org. Geochem. 32, 647-665. doi:10.1016/ S0146-6380(01)00017-1

Stankiewicz, B. A., Briggs, D. E. G., Michels, R., Collinson, M. E., and Evershed, R. P. (2000). Alternative origin of aliphatic polymer in kerogen. Geology 28, 559-562. doi:10.1130/0091-7613(2000)28<559:AOOAPI > 2.0.CO;2

Tegelaar, E. W., de Leeuw, J. W., Derenne, S., and Largeau, C. (1989). A reappraisal of kerogen formation. Geochim. Cosmochim. Acta 53, 3103-3106. doi:10.1016/ 0016-7037(89)90191-9

Tissot, B., and Welte, D. H. (1984). Petrol. Form. and Occurr, 2nd Edn. Berlin: Springer-Verlag.

Versteegh, G. M. J., Blokker, P., Wood, G. D., Collinson, M. E., Damsté, J. S. S., and de Leeuw, J. W. (2004). An example of oxidative polymerization of unsaturated fatty acids as a preservation pathway for dinoflagellate organic matter. Org. Geochem. 35, 1129-1139. doi:10.1016/j.orggeochem.2004.06.012

Watson, J. S., Fraser, W. T., and Sephton, M. A. (2012). Formation of a polyalkyl macro-molecule from the hydrolysable component within sporopollenin during 
heating/pyrolysis experiments with Lycopodium spores. J. Anal. App. Pyr. 95, 138-144. doi:10.1016/j.jaap.2012.01.019

Conflict of Interest Statement: The author declares that the research was conducted in the absence of any commercial or financial relationships that could be construed as a potential conflict of interest.
Copyright $\odot 2015$ Gupta. This is an open-access article distributed under the terms of the Creative Commons Attribution License (CC BY). The use, distribution or reproduction in other forums is permitted, provided the original author(s) or licensor are credited and that the original publication in this journal is cited, in accordance with accepted academic practice. No use, distribution or reproduction is permitted which does not comply with these terms. 